\title{
PRELIMINARY STUDY OF THE IMPACT OF GUADALHORCE RIVER MOUTH CHANNELING (MÁLAGA, SPAIN) ON GROUNDWATER AND RELATED WETLANDS
}

J.M. Nieto-López (\&) B. Andreo-Navarro J.A. Barberá-Fornell

Department of Geology and Centre of Hydrogeology

University of Málaga (CEHIUMA), 29071 Málaga, Spain

e-mail: nietolopezjm@uma.es

J.M. Ramírez-González

Andalusian Regional Agency of Environment and Water, 29001 Málaga, Spain

M. Rendón-Martos

Andalusian Regional Office of Environment and Land Management, 29520 Fuente de Piedra, Spain

\begin{abstract}
In riverine areas, many anthropogenic actions (modification of natural water courses, burying or channeling works, etc.) have been commonly applied worldwide to prevent floods in rivers, having negative environmental impacts on their dependent ecosystems. In the Guadalhorce River mouth (Málaga, Southern Spain), channeling works -including the splitting of the main channel into two branches before arriving to the sea- were conducted to reduce the flood risk in the surrounding urbanized areas near to the Mediterranean coast. In the framework of the monitoring program of the Guadalhorce Delta Wetlands, located between the branches of the ending river stretch, measurements of electrical conductivity in wetland water and groundwater table were performed, as well as the sampling of both water types. The results show a progressive increasing in the mineralization of wetland water, reaching values 50 times higher than the original ones. In the underlying aquifers, the mineralization of groundwater is generally less variable and lower than the recorded in the eighties and nineties, when a salt intrusion episode occurred. Before the river channel modification, the water flow from the aquifer to the wetlands and toward the river in its mouth was deduced. Today, the wetlands recharge locally the Quaternary aquifer and, consequently, induce the groundwater flow towards the both branches of the river and Mediterranean Sea. The variation of the morphodynamics in the Guadalhorce River mouth and the associated changes in land use have caused significant impacts on ground and surface water and their dependent wetlands.
\end{abstract}

Key words: Channelling, Guadalhorce River, Coastal aquifers, Wetlands, Spain 